\title{
CORRECTION
}

View Article Online

View Journal I View Issue

D) Check for updates

Cite this: Phys. Chem. Chem. Phys., 2017, 19, 11709

DOI: $10.1039 / c 7 c p 90081 c$

rsc.li/pccp

\section{Correction: A molecular dynamics study of the ionic liquid, choline acetate}

\author{
Jon A. L. Willcox, ${ }^{a}$ Hyunjin Kim ${ }^{a}$ and Hyung J. Kimªb
}

Correction for 'A molecular dynamics study of the ionic liquid, choline acetate' by Jon A. L. Willcox et al., Phys. Chem. Chem. Phys., 2016, 18, 14850-14858.

The values for the bond force constants used in our simulations were listed incorrectly in Table 2 of the published article. In order to reproduce the data reported in the paper, one would need the revised parameters listed in this correction.

Table 2 Bond parameters used for choline and acetate ions

Bond parameters

\begin{tabular}{lllr}
\hline Atom & Atom & $r_{0}(\mathrm{~nm})$ & $k_{\mathrm{b}}\left(10^{3} \mathrm{kcal} \mathrm{mol}^{-1} \mathrm{~nm}^{-2}\right)$ \\
\hline $\mathrm{H}_{1}$ & $\mathrm{C}_{2}$ & 0.1080 & 60.0 \\
$\mathrm{C}_{2}$ & $\mathrm{~N}_{3}$ & 0.1510 & 43.0 \\
$\mathrm{~N}_{3}$ & $\mathrm{C}_{4}$ & 0.1510 & 43.0 \\
$\mathrm{C}_{4}$ & $\mathrm{H}_{5}$ & 0.1080 & 60.0 \\
$\mathrm{C}_{4}$ & $\mathrm{C}_{6}$ & 0.1530 & 44.5 \\
$\mathrm{C}_{6}$ & $\mathrm{H}_{7}$ & 0.1111 & 61.8 \\
$\mathrm{C}_{6}$ & $\mathrm{O}_{8}$ & 0.1420 & 85.6 \\
$\mathrm{O}_{8}$ & $\mathrm{H}_{9}$ & 0.0960 & 109.0 \\
$\mathrm{H}_{10}$ & & 0.1111 & 64.4 \\
$\mathrm{C}_{11}$ & $\mathrm{C}_{11}$ & 0.1522 & 40.0 \\
$\mathrm{C}_{12}$ & $\mathrm{C}_{12}$ & 0.1260 & 105.0
\end{tabular}

The Royal Society of Chemistry apologises for these errors and any consequent inconvenience to authors and readers.

\footnotetext{
${ }^{a}$ Department of Chemistry, Carnegie Mellon University, 4400 Fifth Ave, Pittsburgh, PA 15213, USA. E-mail: hjkim@cmu.edu

${ }^{b}$ School of Computational Sciences, Korea Institute for Advanced Study, Seoul 02455, Korea
} 